\title{
Altitudinal variation of species composition of small non-flying mammals in the Yungas region of Bolivia
}

\author{
Adriana Rico-Cernohorska ${ }^{1 *}{ }^{2}$, Jorge Salazar-Bravo ${ }^{1,4}$, José Martínez ${ }^{1}$, Susana G. Revollo-Cadima ${ }^{1}$, and Pavel Kindlmann 2,5 \\ ${ }^{1}$ Colección Boliviana de Fauna, Instituto de Ecología, Carrera de Biología, Universidad Mayor de San Andrés, Campus Universitario, \\ Calle 27 Cota Cota, 10077. La Paz, Bolivia. Email: adri rico cer@yahoo.es; arico@fcpn.edu.bo (ARC), j.salazar-bravo@ttu.edu \\ (JSB), sussygab@gmail.com (SRC) \\ ${ }^{2}$ Global Change Research Institute Bĕlidla 986/4a 603 00. Brno, Czech Republic. Email: adri rico cer@yahoo.es; arico@fcpn.edu.bo \\ (ARC), pavel.kindlmann@centrum.cz (PK) \\ ${ }^{3}$ Texas Tech University, Department of Biological Sciences, Lubbock, TX 79409-3131, USA. Email: j.salazar-bravo@ttu.edu (JSB) \\ ${ }^{4}$ Instituto Nacional de Biodiversidad, (INABIO), Calle Rumipamba 341 y Av. de los Shyris, PB 17-07-8976, Quito, Ecuador,. \\ ${ }^{5}$ Institute for Environmental Studies, Faculty of Science, Charles University, Prague 2, Czech Republic. Email: pavel.kindlmann@ \\ centrum.cz (PK) \\ ${ }^{*}$ Corresponding author
}

The Cotapata National Park and Natural Area for Integrated Management (PN-ANMI) is located on the eastern escarpments of the Eastern Cordillera in Bolivia. It has an altitudinal range between 1,100 to 5,600 masl, with five altitudinally delimited ecological zones. There is great variability of environments, which generates great animal species diversity, varying according to elevation, and in association with changes in climatic and ecological conditions. The aim of this study was to determine the pattern of richness and composition of small non-flying mammals along an altitudinal gradient in the PN-ANMI Cotapata and to evaluate responses of these species to the gradient. We worked at three different elevations: Yungas Forest (1,400 masl), Cloud Forest (2,100 masl) and Yungas Paramo (3,500 masl). Six temporary replicas were conducted. For each sampling period we run three $250 \mathrm{~m}$ linear transects were placed, separated by $50 \mathrm{~m}$ attitudinally. Each transect contained 25 sampling stations, with two snap traps. With the exception of Yungas Paramo (due to the rocky ground), we also run transects of pitfall barrier traps (five buckets, every $5 \mathrm{~m}$ ). We captured 460 specimens corresponding to 20 species of rodents and two of marsupials. Although, species richness $(S)$ and diversity (Cinv) were higher in Cloud Forest (intermediate elevation; $S=11$, Cinv $=4.30$ ), followed by Yungas Forest $(S=9$, Cinv = 3.47), and lower in Yungas Paramo (higher elevation; $S=8$, Cinv $=2.12)$, only the diversity was significantly different $(H=7.0, n=17, P=0.03$ ). Species composition varied between places, showing the greatest turnover between Cloud Forest and Yungas Paramo, with a similarity of only $2 \%$. Yungas Paramo had the highest number of exclusive species (seven of the eight registered). The diversity was higher at medium altitude, giving a positive monoclinal hump-shaped pattern. This variation, responds to climatic influences associated with changes in vegetation, where Cloud Forest provides a greater diversity of ecological niches. The lower diversity in Yungas Paramo, and the almost total species turnover responds to inhospitable and stress conditions and to the physiological adaptations of these species to these elevations.

El Parque Nacional y Área Natural de Manejo Integrado Cotapata (PN-ANMI) se encuentra en la región cordillerana oriental de Bolivia. Presenta intervalo altitudinal desde 1,100 hasta 5,600 msnm, albergando cinco pisos ecológicos limitados altitudinalmente. Esto genera una gran variabilidad de ambientes, no solo entre pisos ecológicos, sino al interior de los mismos. Esta variabilidad genera una gran diversidad de especies animales que variaría según el incremento en la elevación y; por ende, al cambio en las condiciones climáticas y ecológicas asociadas. Así, este estudio busca determinar el patrón de la riqueza y composición de pequeños mamíferos no voladores a lo largo de un gradiente altitudinal en el PN-AMNI Cotapata y evaluar las respuestas de estas especies a dicho gradiente. Se trabajó en tres diferentes elevaciones que coinciden con los tres pisos ecológicos inferiores: Bosque Yungueño (1,400 msnm), Bosque Nublado (2,100 msnm) y Páramo Yungueño (3,500 msnm). Se realizaron seis réplicas temporales (épocas seca y húmeda y sus transiciones). En cada muestreo se colocaron tres transectos lineales de $250 \mathrm{~m}$, separados altitudinalmente por al menos $50 \mathrm{~m}$. Cada transecto contenía 25 estaciones de muestreo, con dos trampas golpe. En el Bosque de Yungas y Bosque Nublado se colocaron tres y dos transectos de trampas de barrera pitfall (respectivamente) con cinco baldes cada una, separados por cinco metros; en el Páramo Yungueño no se los pudo instalar debido al suelo rocoso. Se capturaron 460 especímenes correspondientes a 20 especies de roedores y dos de marsupiales. Si bien riqueza (S) y diversidad (Inverso de Simpson, Cinv) de especies fueron mayores en el Bosque Nublado (elevación intermedia; $S=11$, Cinv $=4.30$ ); seguido por el Bosque Yungueño $(S=9, C i n v=3.47)$ y menor en el Páramo Yungueño (mayor elevación; $S=8$, Cinv $=2.12$ ); solo la diversidad fue significativamente diferente $(H=7.0, n=17, P=0,03$ ). La composición de las especies varió entre los pisos, observándose una mayor diversidad beta entre Bosque Nublado y Páramo Yungueño, con una similitud de solo del 2 \%. Páramo Yungueño presentó el mayor número de especies exclusivas (siete de las ocho registradas). La diversidad fue mayor a altitud media (Bosque Nublado), dando un patrón monoclinal positivo con forma de joroba. Esta variación, y en especial el recambio de especies observado, particularmente entre los dos pisos ecológicos superiores, respondería a las influencias climáticas asociadas con cambios en la vegetación, donde Bosque Nublado proporcionaría una mayor diversidad de nichos. La menor diversidad en el Páramo Yungueño, y el recambio casi total de sus especies respondería a las condiciones inhóspitas y de estrés climático, donde especies con adaptaciones fisiológicas a dichas condiciones tendrían una ventaja competitiva.

Keywords: altitudinal gradient; Cotapata National Park; distribution; rodents; eastern mountain range; non-volant small mammals; replacement.

@ 2020 Asociación Mexicana de Mastozoología, www.mastozoologiamexicana.org 


\section{Introduction}

Environmental gradients, such as latitude, altitude, sea depth, are responsible for the perceived patterns of abundance, distribution, and diversity of organisms on earth (Brown 2001). The decline in species richness from the equator to the poles is one of the most universal biogeographic patterns, demonstrated in a variety of taxa in aquatic and terrestrial ecosystems (Rahbek 1995). A similar pattern has been suggested to occur in altitudinal gradients, with richness decreasing monotonically as elevation increases (Stevens 1992; Brown 2001), as observed for neotropical birds (Terborgh 1977; Brown 1988; Herzog et al. 2005) and amphibians (Navas 2006). Altitudinal gradients are particularly important because they are often associated with abiotic gradients (climate, humidity and exposure), which in turn may generate structural complexity and habitat heterogeneity (Körner 2007; Heaney 2001; Lomolino 2001). Further, increased structural complexity and habitat heterogeneity provide resources (e.g., food and shelter), which generate intra- and interspecific competition (MacArthur and MacArthur 1961). All these factors have an impact on the richness, diversity and species assemblage of a given location (Luévano et al. 2008; Cruz et al. 2010) and, therefore, on alpha or beta biodiversity (Lomolino 2001; Sanders and Rahbek 2012).

Changes in species richness are not necessarily monotonic or clinal (increasing or decreasing; Rahbek 1995; Sanders and Rahbek 2012), and may be unimodal (humpshaped pattern) positive or negative (Rosenzweig 1992). Several studies, conducted on small non-flying mammals in various regions of the world found unimodal (humpshaped) patterns with peaks of richness at medium elevation (Patterson et al. 1998; Kelt 1999; Heaney 2001; Md Nor 2001; Rickart 2001; Sánchez-Cordero 2001; McCain 2003, 2004). This pattern corresponds to the predictions proposed by the null model hypothesis of the mid-elevation domain (Colwell and Hurtt 1994; Colwell and Lees 2000). McCain $(2005,2007)$ analyzed the relationship between elevation and species richness of small mammals and found a clear pattern of medium elevation peaks in species richness (humped pattern), although few data completely matched the predictions of the null model. These and subsequent studies ruled out the null model as responsible for this pattern (Currie and Kerr 2008; Bateman et al. 2010; Andrade and Monjeau 2014), where ecological factors such as climate (temperature, precipitation), productivity, and habitat heterogeneity provide environmental explanations for the richness gradients.

In South America, Mena et al. (2011) reviewed the work done in the tropical Andes and the relationship of elevation with the diversity of small non-flying mammals (mainly in Peru and Colombia). There is no consensus on a general pattern that describes how small mammal fauna diversity changes with elevation in the Neotropics (Patterson et al. 1989, 1998; Villalpando 2004; Vivar 2006; Swenson et al. 2012; Andrade and Monjeau 2014; Moya et al. 2015;
Vargas et al. 2018; Solari et al. 2006; Novillo and Ojeda 2014). More detailed and precise information is required, in order for the relationship between diversity and elevational gradients, and ecology and biogeography of small nonflying mammals, to be better understood.

Recent various reports combined metacommunity structure with studies on biodiversity gradients along multiple dimensions of biodiversity --from taxonomic and phylogenetic to functional -- in the tropical Andes (Presley et al. 2012; Dreiss et al. 2015; Willig and Presley 2016). These studies suggest that communities of small nonflying mammals were composed of habitat specialists (Presley et al. 2012), and that changes in composition were always associated with ecotones between major ecological zone (Willig and Presley 2016). Dreiss et al. (2015) found that species richness was highly correlated with phylogenetic biodiversity, and this with functional biodiversity. They also found that richness was better explained by high vertical vegetation complexity and high productivity of rainforests.

The eastern escarpments of the Andes range from 800 and more than 6,000 masl and are marked by complex topography and steep slopes, which in combination generate a very complex mosaic of plant formations and a great diversity of species (Beck 1988; Ribera-Arismendi 1995).

Small mammal richness in Bolivia is well-recognized (Anderson 1997; Salazar-Bravo et al. 2002, 2003; Wallace et al. 2010; Aguirre et al. 2019), and it continues to increase year by year. The mammalian fauna of the region is relatively well known (Villalpando 2004; Solari 2007; Mena et al. 2011; Vargas et al. 2018; Identidad Madidi and SERNAP 2019, among others), comparatively little is known about the ecology or the patterns of co-occurrence and interactions among the species present on the region (Dreiss et al. 2015). The goal of this study was to determine the pattern of richness and composition of small non-flying mammal communities along an altitudinal gradient in Cotapata National Park, as well as to evaluate the responses of these species to this gradient in elevation.

\section{Methods}

Study area. This study was conducted in the Cotapata National Park and Integrated Management Natural Area (PN ANMI, $-16^{\circ} \mathrm{S}$ and $-68^{\circ} \mathrm{W}$, Cotapata hereon) located NE of the city of La Paz, on the eastern slope of the Eastern Cordillera, in the Yungas Biogeographic Sector (Navarro and Maldonado 2002; Sevilla-Callejo and Mata-Olmo 2007). Cotapata has an estimated area of 56,620 ha, but due to the irregularity of the relief, it could cover an area of more than 80,000 ha. The area ranges from 1,100 to 5,600 masl (Ribera-Arismendi 1995; Sevilla-Callejo and Mata-Olmo 2007; Figure 1). Altitudinally, it covers six ecological zones: Nival (above 5,000 masl), Subnival, High Andean, Yungas Paramo, Yungas Cloud Forest (mountain ridge), and Yungas mountain rain forest (1,100 masl; Ribera-Arismendi 1995). It presents two main climate types: polar of high mountain and humid mesothermic with summer rains and dry and 
warm winters (Cloud Forest and Yungas Forest; RiberaArismendi 1995), generating a dry and humid season.

The fieldwork was done to cover the greatest possible altitudinal extension, covering the last three ecological floors, with an altitudinal range from 1,200 masl (Yungas Forest) to 4,200 masl (Yungas Paramo). The inferior floor is the Yungas Forest that goes from the 1,200 to 2,400 msnm, with humid subtropical climate, annual precipitation less than $2,000 \mathrm{~mm}$ and temperatures between 12 and $17^{\circ} \mathrm{C}$. It presents a greater seasonality, with a marked dry season between June and September (Ribera-Arismendi 1995). It is located on steep slopes, in relatively wide alluvial valleys and deep gorges. The forest on this floor is of medium height, where the upper stratum is dense and continuous between 15 and $20 \mathrm{~m}$, with emergents of up to $30 \mathrm{~m}$ (Ficus spp., Aniba spp.) and the lower strata are very dense (Ribera-Arismendi 1995). It is followed by the Cloud Forest that extends from 2,200 to 2,300 to 3,300 to 3,500 masl and whose topography is made up of ridges, hilltops, and very steep and deep gorge slopes, where its slopes have a strong exposure to humid air masses (Ribera-Arismendi 1995). The climate is predominantly cold and perhumid, characterized by frequent rain and orographic drizzle, with an influx of wetting fog (horizontal rain) throughout the year. Rainfall exceeds 3,000 $\mathrm{mm}$ per year. Seasonality is diffuse, with drier periods between August and September (RiberaArismendi 1995). The forest on this floor has a canopy height between 10 and $15 \mathrm{~m}$ on average, with scattered emergence of Miconia theaenazas of up to $30 \mathrm{~m}$. The lower stratum is very dense and rich in lianas, tangle of bamboo Chusquea spp. and lianescent shrubs; as well as ferns, bromeliads, and orchids (Ribera-Arismendi 1995). The floor of Yungas Paramo is located between 3,300 and 4,200 masl. The weather is dominated by high humidity (drizzles and wetting fogs almost all year round) hyperhumidity (soil generally saturated with water) with annual rainfall above $1,400 \mathrm{~mm}$, and a short dry period between August and September. Average daily temperatures are less than $10^{\circ} \mathrm{C}$ (Ribera-Arismendi 1995). This area generally extends over mountain peaks and plateaus that are surrounded by the cloud forests of the surrounding valleys. This floor is covered by a thick layer of organic matter and humus of the Mor type, where mosses, lichens (Cora pavinona) and fungi grow, alternating with a rich flora of low growing camephites (Perezia spp, Hypochoeris spp., Liabum ovatum spp., among others) and small dispersed stands of Polylepis pepei queñua, mountain Buddleja (Kishuara) shrubs and Bacharis pentlandii forests (Ribera-Arismendi 1995).

Sampling. The sampling was conducted on the gradient between 1,200 and 3,600 masl (Figure 1), and from 2007 to 2009. Due to accessibility and the steep slopes, three altitudinal surveys were conducted, which co-incide with the three lower ecological floors of the National Park. Thus, Chairo $(1,200$ to 1,600 masl) was selected to represent the Yungas Forest (lower sampling margin is provided by the Huarinilla River; Figure 1). The locality of Alto Nogalani
$(2,100$ to 2,300 masl) was selected as one representing the ecological floor of the Cloud Forest unit. Finally, the plateau of Hichuloma (3,400 to 3,600 masl) that sampled as a representative of the Yungas Paramo. With the exception of Alto Nogalani, which presents some plots of family crops (which were not part of the sampling), the remainder of the study sites have very little human intervention. Six temporal replicates, of seven nights of sampling each, were conducted in the study sites: July 2007 (dry season), September 2007 (dry-wet transition), February 2008 (wet season), August 2008 (dry season), October 2008 (dry-wet transition), and April 2009 (wet-dry transition); in the latter, sampling could not be conducted at the altitude of 3,600 meters above sea level. Three linear transects each of ca. $250 \mathrm{~m}$, were placed at each elevation. Each transect had 25 sampling stations (with two snap traps: a special Museum and a Victor trap) separated by 10 meters. The traps were baited with a mixture of tuna, oats and vanilla essence (Santos et al. 2007; Luévano et al. 2008; Cruz et al. 2010) and checked early in the morning. Additionally, to have a better record of the richness of each site, in the Yungas Forest and the Cloud Forest, three and two transects of pitfall barrier traps were placed, respectively. Each pitfall trap transect had five buckets ( $25 \mathrm{~cm}$ in diameter) separated by $5 \mathrm{~m}$. In the Yungas Paramo they were not placed due to the rocky structure of the soil. At all sampling sites, traps were set for seven consecutive nights, for a total of 17,850 night traps and 1,050 pitfall-nights (Table 1).

Processing of the specimens. All specimens were handled following the guidelines of the American Society of Mammalogy (ad hoc Committee on Acceptable Field Methods in Mammalogy 1998; Gannon et al. 2007) and were processed in the field. Standard measurements, gender, and reproductive status were obtained recorded for all specimens (Santos et al. 2007). Specimens were identified according to Anderson (1997), Patton et al. (2000), Salazar-Bravo et al. (2002), Salazar-Bravo et al. (2003), Voss et al. (2004), Villalpando et al. (2006), Weksler et al. (2006),

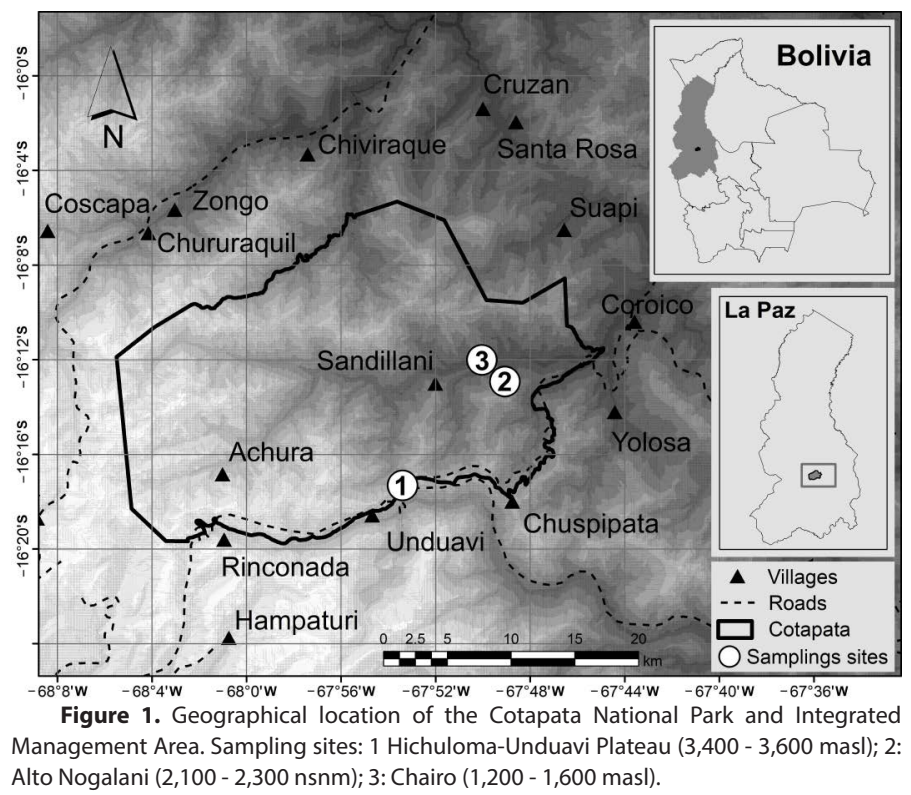


Patton et al. (2015), Hurtado and Pacheco (2017), among others, and reference specimens from the Bolivian Collection of Fauna (CBF).

Data analysis. Capture effort was estimated by multiplying the number of traps used each night by the number of nights traps were deployed (trap-nights). The relative abundance was obtained from the capture effort. Species accumulation curves (Chao 1 and Chao 2) were used to estimate the representativeness of the sampling in each of the ecological zones. The Chao 1 estimator considers abundance, while the Chao 2 estimator is based on species incidence (Escalante 2003). Although it was not possible to sample Yungas Paramo in 2009, overall the sampling effort was homogeneous within each altitudinal floor; therefore, the results are considered comparable across sites and years. Individuals collected in pitfall traps were considered only for the calculation of relative abundance, since preliminary analyses showed no differences with diversity, but they are important for the richness data. Species richness $(S)$ considered as the number of species and absolute abundance (total number of individuals of all species) were estimated per ecological zone. Diversity and equitability (ranging from 0 to 1 ) were estimated using Simpson's inverse index (Cinv; Begon et al. 2006) which is a better indicator when working with small populations as it is less sensitive to rare species (Begon et al. 2006). Alpha diversity was calculated by combining results of all temporal replications, for all species, at each of the three sampled ecological zones. Gamma diversity was estimated by combining species records at each elevation. To determine if there are significant differences in relative abundance and diversity among the three ecological floors sampled, we used Kruskal-Wallis test, because the data did not meet the assumption of normality (Zar 2010). To determine the differences between pairs of ecological zones we used $U$ Mann-Whitney (with Bonferroni correction) using the SPSS v19 statistical package (Norušis and SPSS Inc. 1990). Since diversity is an index that does not show species composition, rank-abundance curves were plotted to determine differences in species composition and abundance at each ecological zone. Finally, we used the Morisita-Horn quantitative similarity coefficient in PAST v 403 statistical package (Hammer et al. 2001), to determine the similarity in species composition among the three floors: Yungas Paramo, Cloud Forest and Yungas Forest.

\section{Results}

We captured 460 specimens, corresponding to 20 species of the order Rodentia ( $96.74 \%$ abundance) and two of the order Didelphimorphia. Of these, 402 specimens were captured with snap traps and 58 in pitfall (Table 1). The number of species found per ecological zone (each elevation sampled) throughout the study period varied from 2 to 10 , and the number of animals captured varied from 11 to 53 (Table 1). The most abundant species was Akodon mimus with more than $25 \%$ of the individuals captured, although it was captured only in the Yungas Paramo (Table 3). It was followed in abundance by Akodon baliolus, Nephelomys levipes and Neacomys vargasllosai, with abundances between 10 and $15 \%$ (Table 2). Less abundant (3 to $7 \%$ ) were Oligoryzomys occidentalis, Oligoryzomys destructor, Microryzomys minutus and the marsupial Marmosops noctivagus (Table 2), followed by Thomasomys sp1, Oecomys phaeotis and Oxymycterus nigrifrons (with just over $1 \%$ ). The remainder of the species collected $(n=11)$ did not exceed $1 \%$ and were thus considered rare species (Table 2).

The relative abundance of the set of temporary replicates did not vary between the elevations $(H=3.12$, $n=26, P=2.11)$, although the Yungas Paramo $(n=199, S$ $=8$, Cinv $=2.12$ ) presented a greater relative abundance than the Cloud Forest $(n=134, S=9, \operatorname{Cinv}=3.32)$ and this in turn, more than the Yungas Forest $(n=69, S=9$, Cinv $=2.85$; Table 1). Species accumulation curves per ecological zone plateaud in species richness before the end of the study

Table 1. Capture effort (snap traps, pitfall) along transects for each elevation with their seasonal replicas, including the species richness and number of individuals captured. Altitudinal range: Yungas Forest 1250-1600 masl; Cloud Forest: 2100-1600 mnsnm; Yungas Paramo: 3450-3550 masl. Capture effort: Yungas Forest 1050 traps/night and 105 pitfall/night; Cloud Forest: 1050 traps/night and 70 pitfall/night; Yungas Paramo: 1050 traps/night and no pitfall. D: Dry season; W: Wet season; D-W: Transition from dry to wet; W-D: Transition from wet to dry.

\begin{tabular}{|c|c|c|c|c|c|c|c|c|}
\hline \multirow{2}{*}{ 苋 } & \multirow{2}{*}{ Year } & \multirow{2}{*}{$\begin{array}{c}\text { Capture effort } \\
\text { Season }\end{array}$} & \multicolumn{2}{|c|}{ Both methods } & \multicolumn{2}{|c|}{ Snap traps } & \multicolumn{2}{|c|}{ Pitfall } \\
\hline & & & \# sp & \# Indiv & \# sp & \# Indiv & \# sp & \# Indiv \\
\hline & 2007 & D: jul & 4 & 11 & 4 & 11 & 0 & 0 \\
\hline పั & & D-W: sep & 6 & 23 & 5 & 19 & 4 & 4 \\
\hline$\overline{\check{\sigma}}$ & & W: dec-7-feb 8 & 6 & 13 & 5 & 8 & 3 & 5 \\
\hline$\sum$ & 2008 & D: ago & 2 & 11 & 2 & 10 & 1 & 1 \\
\hline$\stackrel{\widetilde{E}}{\varepsilon}$ & & D-W: oct & 7 & 31 & 5 & 12 & 5 & 19 \\
\hline$\stackrel{5}{5}$ & 2009 & W-D: apr & 2 & 11 & 2 & 9 & 1 & 2 \\
\hline \multicolumn{2}{|c|}{ Sub total } & & 9 & 100 & 9 & 69 & 6 & 31 \\
\hline & 2007 & D: jul & 5 & 24 & 5 & 24 & 0 & 0 \\
\hline 莺 & & D-W: sep & 10 & 47 & 7 & 39 & 6 & 8 \\
\hline$\overline{0}$ & & W: dec-7-feb 8 & 5 & 22 & 3 & 17 & 3 & 5 \\
\hline$\stackrel{\cup}{n}$ & 2008 & D: ago & 6 & 14 & 6 & 14 & 0 & 0 \\
\hline ¿ & & D-W: oct & 7 & 30 & 4 & 21 & 5 & 9 \\
\hline $\bar{N}$ & 2009 & W-D: apr & 6 & 24 & 6 & 19 & 3 & 5 \\
\hline \multicolumn{2}{|c|}{ Sub total } & & 11 & 161 & 9 & 134 & 7 & 27 \\
\hline$\widehat{0}$ & 2007 & D: jul & 5 & 42 & 5 & 42 & - & - \\
\hline$\frac{5}{2}$ & & D-W: sep & 6 & 27 & 6 & 27 & - & - \\
\hline$\sum_{2}^{2}$ & & W: dec-7-feb 8 & 6 & 28 & 6 & 28 & - & - \\
\hline$\stackrel{\text { है }}{\text { है }}$ & & D: ago & 4 & 53 & 4 & 53 & - & - \\
\hline$\stackrel{n}{m}$ & 2008 & D-W: oct & 6 & 49 & 6 & 49 & - & - \\
\hline \multicolumn{2}{|c|}{ Sub total } & & 8 & 199 & 8 & 199 & - & - \\
\hline \multicolumn{2}{|c|}{ Total } & & 22 & 460 & 20 & 402 & 9 & 58 \\
\hline
\end{tabular}


period (Figure 2). Thus, each elevation was considered adequately sampled to evaluate the differences in species richness and composition among the three elevations (ecological zones). The estimated number of species at each elevation, according to the Chao 1 and 2 estimators, are nine species for Yungas Forest, 11 for Cloud Forest, and approximately nine species for Yungas Paramo (one more than the observed observed).

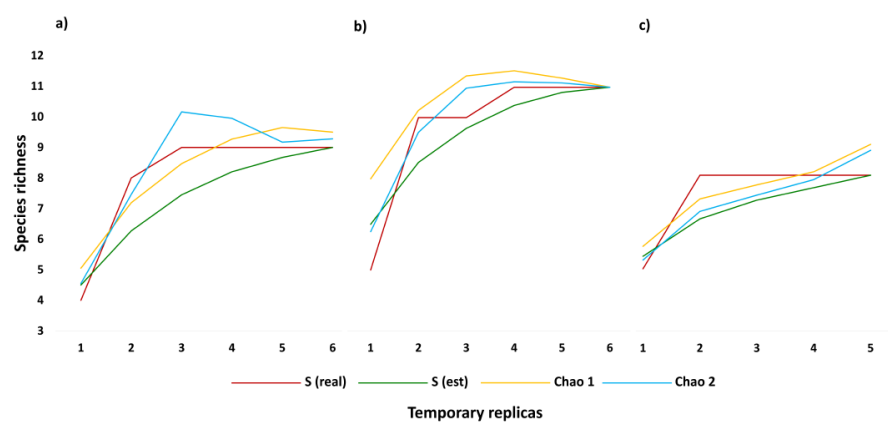

Figure 2. Species accumulation curves for the three elevations (ecological zone) evaluated. a) 1,400 masl (Yungas Forest); b) 2,100 masl (Cloud Forest; c) 3,500 masl (Yungas Paramo). X axis: 1: Dry Season: July 2007. 2: Dry-Wet Season: September 2007; 3: Wet Season: December-2007-February 2008; 4: Dry Season: August 2008; 5: Dry-Wet Season: October 2009; 6: Wet-Dry Season: April 2009. Y axis: Number of species. $S$ (real): real richness; $S$ (est): estimated richness.

The species richness (per temporal replications), while showing seasonal variations (Figure 3a), all peaked at mean elevation (i.e., Cloud Forest), except for the wet season of 2007-2008; however, the differences were not significant $(S=9, H=1.29, n=17, P=0.5$; Table 2 ). Species diversity and species richness showed similar patterns (Figure $3 \mathrm{~b}$ ). As in the case of richness, the diversity of the 2007-2008 wet season differed from the remainder of the seasons and is the only one that presents a decrease as elevation increases (Figure 3b). Unlike richness, diversity did present significant differences overall $(H=7.0, n=17, P=0.03$; Table 2$)$, as well as between the Cloud Forest and the Yungas Paramo $(U=$ $0.00, n=11, P=0.004)$. Other two-pair comparisons showed no significant variations in species diversity: Yungas Forest vs Cloud Forest, $U=9, n=12, P=0.18$, and Yungas Forest -vs Yungas Paramo, $U=10, n=11, P=0.43$, even though the latter two did not share even a single species (Table 2).
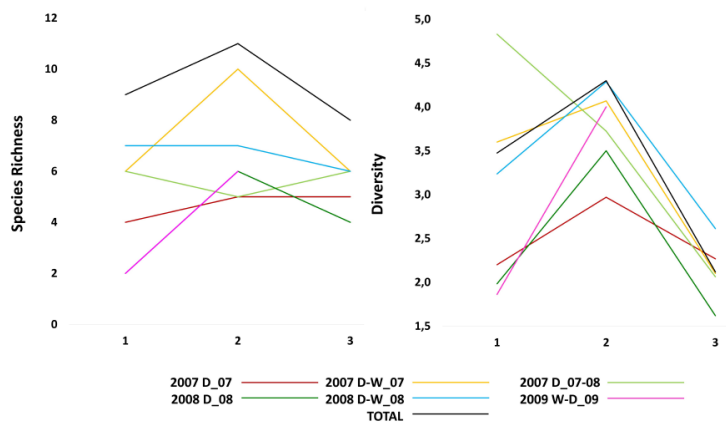

a)

Elevation (masl)

b)

Figure 3. Patterns of a) richness $(S)$ and b) diversity (Cinv) of species for the six temporal replicas. The combined pattern of species richness and diversity. $X$ axis: 1: 1,400 masl (Yungas Forest); 2,100 masl (Cloud Forest); 3: 3,500 masl (Yungas Paramo). Legend: D_07: Dry Season: July 2007; D-W_07: Dry-Wet Season: September 2007; D_07-08: Wet Season: December-2007- February 2008; D_08: Dry Season: August 2008; D-W_08: DryWet Season: October 2008; W-D_09:. Wet -Dry Season: April 2009; Total: includes all species recorded at any given.
Species composition varied among ecological zones (i.e., high beta diversity), especially between the Yungas Paramo and the other two zones (Figure 4). Thus, the Morisita-Horn Index presents a similarity of 0.54 between the lower levels (Yugas Forest and Cloud Forest), and a similarity of only 0.2 between the Cloud Forest and the Yungas Paramo. Beta diversity was maximum between Yungas Forest and Yungas Paramo as these share no species in common (Figure 4). When considering the composition of the species present at each elevation, there was almost $100 \%$ change in the species between the lower levels and the Yungas Paramo (Figure 5). The Yungas Forest and the Cloud Forest share 5 of 15 species, Akodon baliolus, Neacomys vargasllosai, Oligoryzomys destructor, Marmosops noctivagus and Akodon cf. kofordi (from highest to lowest abundance; Table 2, Figure 5). Only Oligoryzomys occidentalis occurs in both Cloud Forest and the Yungas Paramo, being more abundant in the latter (Table 2, Figures 5); while no species are shared between the Yungas Paramo and the Yungas Forest (Table 2, Figure 5).

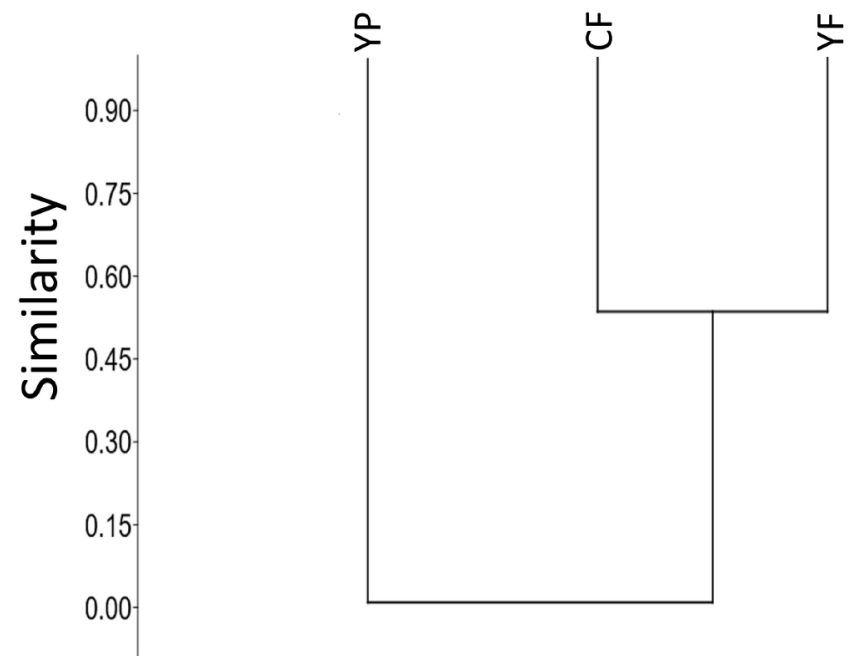

Figure 4. Clustering analysis of the three ecological floors, according to the MorisitaHorn quantitative similarity index. YF: 1,200 masl-Yungas Forest; CF: 2,100 masl-Cloud Forest; YP: 3,500 masl- Yungas Paramo.

The Cloud Forest (intermediate elevation site) was the ecological floor with the highest alpha species richness and diversity (Table 2). Although it was not the most abundant site, it presented relatively high equitability, with several relatively abundant species and few rare species. The species registered as exclusive to this floor were Nephelomys levipes, Rhagomys longilingua, Thomasomys sp. 2, Lenoxus apicalis and Cavia aperea nana (Figure 5b). The Yungas Forest is still rich in alpha diversity, but was the least abundant forest floor; it presented a slightly lower equitability than the Cloud Forest, due to the dominance of Neacomys vargasllosai and Akodon baliolus (Table 2), and the presence of three exclusive species: Hylaeamys yunganus, Rhipidomys austrinus and one species of the genus Proechimys (Figure 5a). The Yungas Paramo was the floor with the least richness and alpha diversity, but where the total number of specimens captured was highest. It also showed the least equitability, due to the dominance and great abundance 


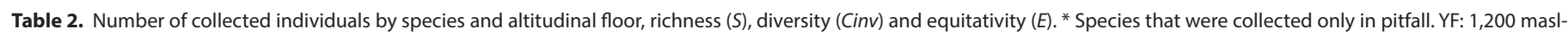
Yungas Forest; CF: 2,100 masl-Cloud Forest; YP: 3,500 masl-Yungas Paramo. Total: Sum of the total number of individuals on each floor.

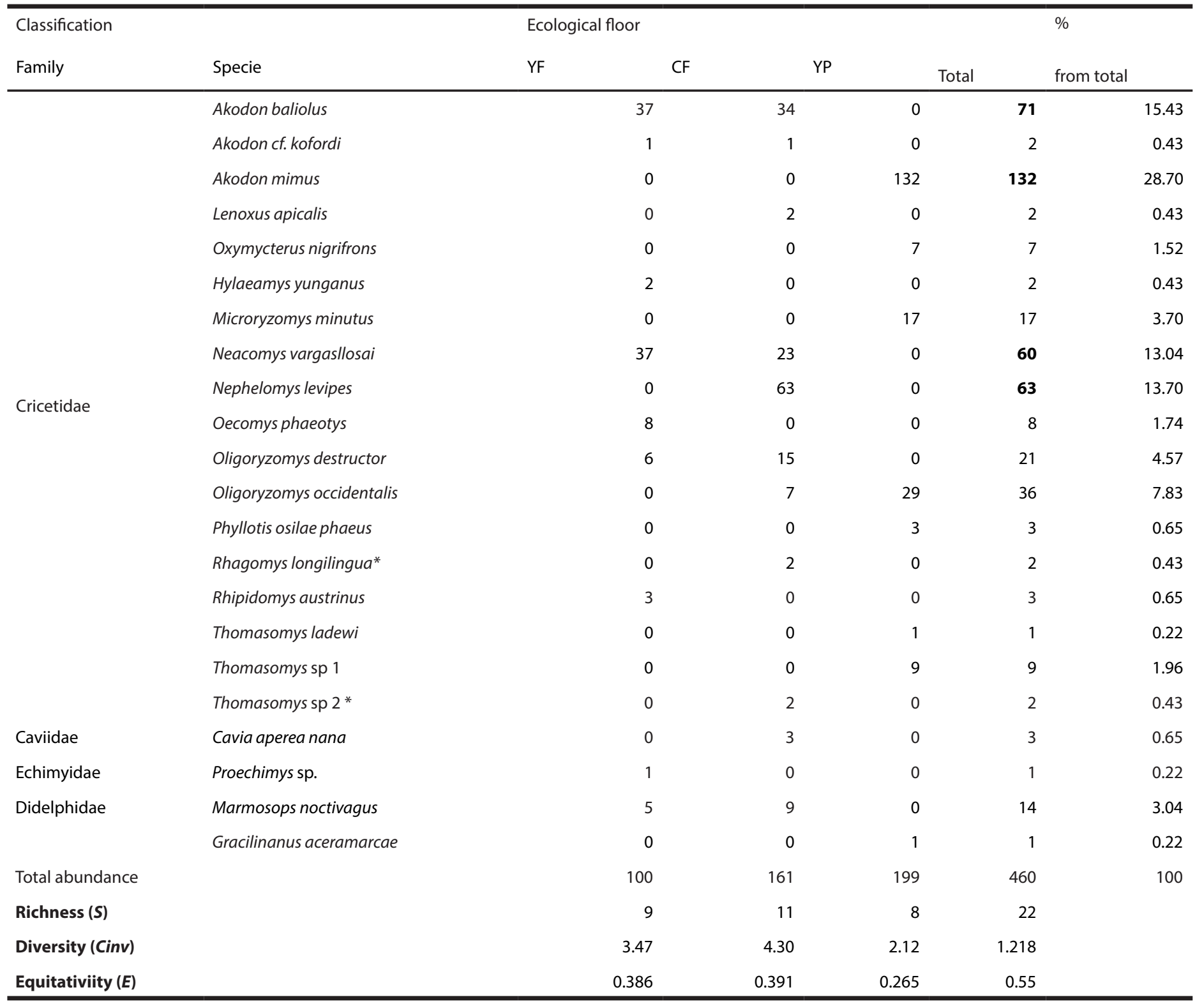

of Akodon mimus, > 130 individuals (Table 2). The largest number and proportion of exclusive species was found on this floor, with seven of its eight species: A. mimus, Microryzomys minutus, Oxymycterus nigrifrons, Phyllotis osilae phaeus, Thomasomys ladewi, Thomasomys sp.1 and Gracilinanus aceramarcae (Figure 5c).

\section{Discussion and conclusions}

In this work, we concentrated our efforts on three of the five ecological zones present along the steep elevation gradient present in the area: we did not sampled Subnival and Nival floors. Sampling was conducted at three elevations, looking for coincidence with the marked ecological zones present in the Yungas zone (Ribera-Arismendi 1995). Although we found that species richness was greatest at middle elevations (Cloud Forest), we found that species richness (number of species) did not vary significantly across ecological zones, but species diversity did. On both cases, our results show a positive monoclinal hump-shaped pattern, where richness and diversity are greater at half of the maximum elevation. This is the pattern predicted by the mean dominance effect (McCain 2005; Currie and Kerr 2008) but see Colwell and Hurtt (1994) and Colwell and Lees (2000), for alternative interpretations. Richness and composition appear to closely track habitat diversity at each ecological floor as has been reported previously (Rahbek 1995; McCain 2005; Körner 2007; Novillo and Ojeda 2014; Brown 2001; Lomolino 2001; McCain 2004). Therefore, the maximum richness should be produced in a point where the environmental conditions are optimal (high productivity and structural diversity) and in the zone of rapid transition between different vegetation communities (Lomolino 2001; Willig and Presley 2016), which in our case would correspond to the Cloud Forest.

Patterson et al. (1998) and Solari et al. (2006) found a decline in the biodiversity of small non-flying mammals 


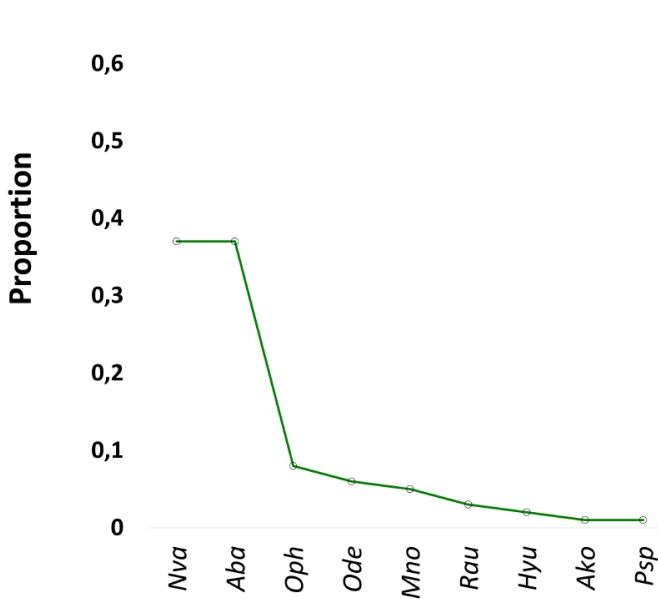

a)

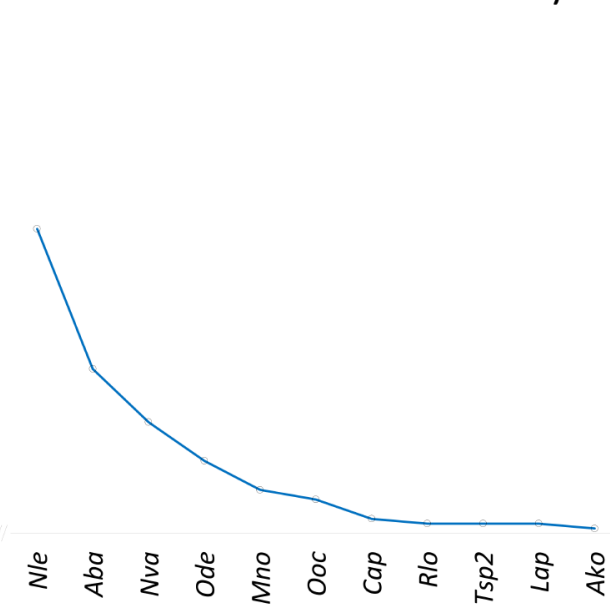

b)

c)

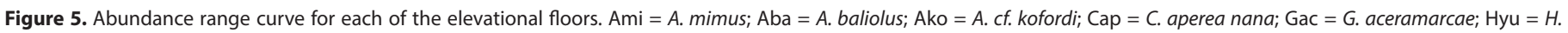

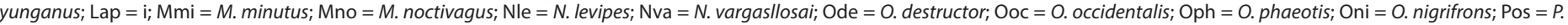
osilae phaeus; Psp = Proechimys sp.; Rau = R. austrinus; Rlo = R. longilingua; Tla = T. ladewi; Tsp1 = Thomasomys sp $1 ;$ Tsp $2=$ Thomasomys sp 2.

in Manu National Park and Biosphere Reserve (Perú) as elevation increased. A similar pattern was observed by Vivar (2006) in the Yanachaga mountain range (Perú). However, Patterson et al. (1998) and Vivar (2006), when conducting the analysis for cricetid rodents only, observed that there was a greater species richness at the ends of the curve (inverse monoclinal). According to Dreiss et al. (2015), all these patterns are explained by the vertical complexity of the vegetation and the higher productivity of rainforests when compared to mountain forests (at higher elevations). In addition, inhospitable and stressful conditions generate physiological restrictions and a competitive exclusion in favor of certain better-adapted clades of cricetid rodents (Mena et al. 2011). In our case, we found greater richness and diversity in the Cloud forest, which would correspond to the cloud forest of Manu and Yanachaga (lower richness). These results do not contradict each other, since for the Cotapata National Park area, the ecological zone of the Cloud Forest has a greater structure in the vegetation (RiberaArismendi 1995) providing a greater diversity of niches.

In addition, due to the accessibility issues and the steep slopes in Cotapata National Park, our sampling concentrated near transition zones, between Yungas Forest and Cloud Forest (2,000 to 2,400 masl), and between Cloud Forest and Yungas Paramo (3,000 to 3,300 masl), which can be considered peak diversity zones as they mark the transition between these communities (Lomolino 2001). The degree of shared species, and therefore the composition and abundance of species, in and between sampling sites, depends on spatial heterogeneity and extension (Pielou 1966; Whittaker 1977; Chaneton and Facelli 1991; Hill and Hamer 2004); that is, local conditions such as type of vegetation and associated food resources (Brown etal.2001). We observe greater diversity and richness at the lower limit of the Cloud Forest, between 2,300 and 2,400 masl, with greater mixing and overlapping of ranges in both directions; while at 3,400 masl, the contribution of higher altitude zones would be less (Lomolino 2001). This is something that should be corroborated with a greater number of sampling points within the ecological floors.

Although the vegetation in the Cloud Forest is structurally more complex than in the Yungas Forest, they share a large number of environmental characteristics, providing a great variety of food and shelter resources. So, the similarity in species composition, especially the presence of the same abundant species (Neacomys vargasllosai and Akodon baliolus) and the observed replacement ( 5 of 15 species) can be explained by the structural complexity. But, also by habitat preference and/or adaptability of each species, where some will be generalists (such as Neacomys vargasllosai, Akodon baliolus, Oligoryzomys destructor, shared and abundant) and other specialists, in relation to the site resources (such as Nephelomys levipes, abundant but exclusive to the Cloud Forest; Willig and Sandlin 1992; Cruz et al. 2010).

Similarly, the above conditions may be responsible for the variation in species richness and composition between the Cloud Forest and the Yungas Paramo. However, other factors must be influencing the reduction in richness and the almost total change of species, which go beyond the climatic conditions. According to Lomolino (2001) as one moves to higher elevations, populations would become more isolated; therefore, immigration rates should decrease and local population extinction rates should increase (Brown and Kodric-Brown 1977). This would explain the lower number of species; but also, and precisely because of this isolation, higher elevation areas may provide the geographic isolation required for speciation (Heaney 2001; Rahbek 1995). It has been suggested the Andes have played a very important role in the speciation of sigmodontine rodents (Reig 1986; Patton and Smith 1992). On the other hand, conditions such as low partial oxygen pressure and low environmental temperatures, present at higher elevations, are a challenge for endothermic species; species living at these altitudes must present certain physiological adaptations to hypoxia, lower temperature, and lower baro- 

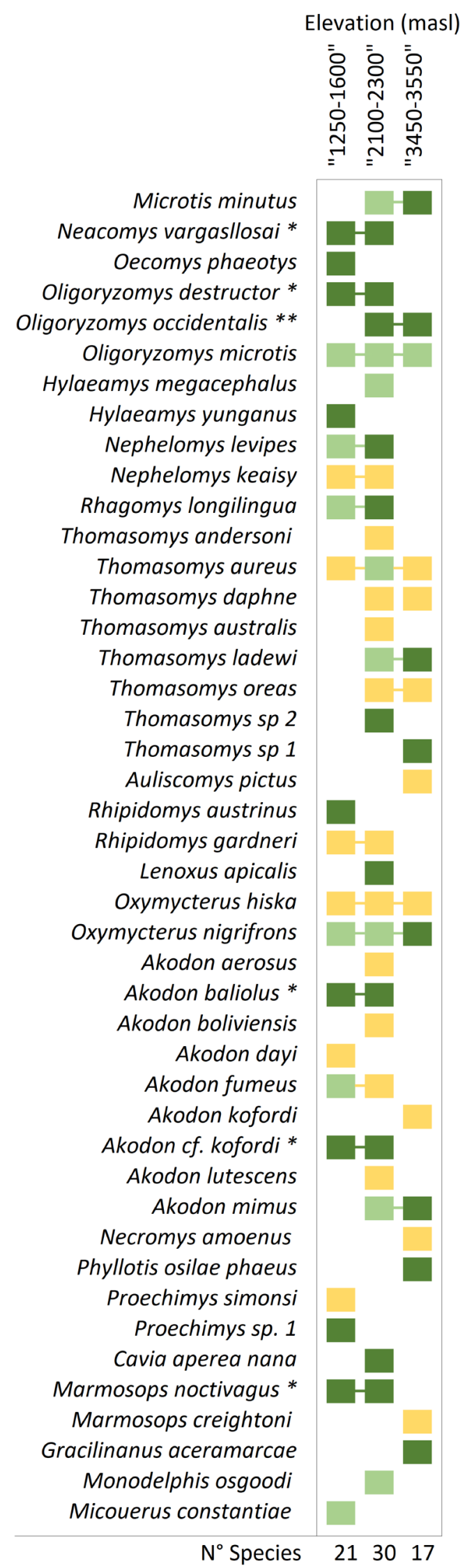

Figure 6. Elevation ranges of each documented species along the sampling transects of this work and according to the literature for the sampling site. Dark-green squares indicate places where the individuals were collected in the present work; the light green squares, in the work of Villalpando (2004) and the yellow squares according to literature. * Species shared between Yungas Forest (YF) and Cloud Forest (CF); ** Species shared between Cloud Forest (CF) and Yungas Paramo (YP). metric pressure (Mena et al. 2011). Thus, the almost complete replacement of species recorded between the Cloud Forest and the Yungas Paramo may, in part, be explained by an ecological filter.

McCain (2009) indicates that species turnover and altitudinal distribution are not only related to changes in climatic conditions (temperature as elevation increases), but also to the latitudinal position of mountains. Thus, in higher latitudinal ranges, the overlap of species along the altitudinal gradient is greater. While at lower latitudes (as in our case), the overlap is less and species turnover is more evident (McCain 2009). This is primarily due to a smaller range of climate variation throughout the day, but also throughout the year (McCain 2009). In our work we can show that, for the eastern slope of the Eastern Cordillera of the Cotapata National Park, for small non-flying mammals, not only is there greater species richness at intermediate elevations (McCain 2005), but the altitudinal range of the species collected is relatively narrow, mainly in the species found at higher elevations, following McCain (2009) prediction.

The pool of potential species in the study zone is deep. A quick review of the literature indicated that several species are expected to occur on our study site but that were not found despite intensive sampling. Among the species reported for the Yungas Paramo zone are eight species: Thomasomys aureus, T. daphne, T. oreas (Anderson 1997; Pacheco 2015), Necromys amoenus (Salazar-Bravo et al. 2002; Pardiñas et al. 2015a), Akodon kofordi (Salazar-Bravo et al. 2002; Pardiñas et al. 2015b), Oxymycterus hiska (de Oliveira and Gonçalves 2015), Auliscomys pictus (Salazar-Bravo 2015; Vargas et al. 2018), Marmosops creightoni (Voss et al. 2004). For the Cloud Forest there are an additional 16 species: Akodon aerosus, A. boliviensis, A. fumeus, A. lutescens, (Anderson 1997; Pardiñas et al. 2015b; Vargas et al. 2018), Oxymycterus hiska, O. nigrifrons, O. paramensis (Villalpando 2004; de Oliveira and Gonçalves 2015), Thomasomys andersoni (Salazar-Bravo and Yates 2007; Pacheco 2015), T. australis, T. ladewi, T. aureus, T. daphne, T. oreas (Anderson 1997; Villalpando 2004; Pacheco 2015), Nephelomys keaysi (Percequillo 2015), Rhipidomys gardneri (Tribe 2015; Aguirre et al. 2019), Monodelphis osgoodi (Villalpando 2004). Lastly, for Yungas Forest, 8 species: Akodon dayi (Anderson 1997; Pardiñas et al. 2015b), A. fumeus (Anderson 1997; Villalpando 2004; Pardiñas et al. 2015b; Vargas et al. 2018), O. hiska (de Oliveira and Gonçalves 2015), T. aureus (Anderson 199; Pacheco 2015), N. keaysi (Percequillo 2015), R. gardneri (Tribe 2015), Proechimys simonsi (Patton and Leite 2015), and Micoureus constantiae (Villalpando 2004; Figure 6).

We restricted our considerable sampling effort to narrow belts of elevation that correspond to major ecological zones. As such, it is possible that that our sampling just failed to include the ribbon-like distributions of several of these potential species. In addition, although our sampling regime was designed to sample a wide range of habitats in each of our sampling units (ecological zones), it is likely that we missed some (or various) of the most restricted habitat 
types. Then, it is not surprising that many rare or "specialists" species may have been missed. In addition, although our experimental design included two snap traps per sampling station, it may be necessary to up the trapping effort register rare species, especially in those sites where one or a few species are common to very abundant, such as is the case of $A$. mimus in Yungas Paramo.

Although this paper does not attempt to analyze the distribution patterns of small non-flying mammals, it is important to highlight the similarities in the altitudinal distribution of the most diverse groups found in this study, which coincide with the work done by Patton (1986) on the eastern slopes of the Peruvian Andes. As in his work, it was evident that there are genera that are restricted only to certain altitudinal ranges, as in the case of Phyllotis or Thomasomys, while others, such as Akodon, Oligoryzomys and Oxymycterus, present a survey of species along the gradient.

The general results presented herein challenge the common-held idea that there is a decline of species diversity with increase elevation. Instead, our work indicates that the patterns predicted by McCain (2009) are maintained, even if one includes species that were not collected at the study site, but are found in these altitudinal ranges (Figure 7). In general, the combination of these results indicate that potential species pools, historical origin of clades, and diversification rates (Quintero and Jetz 2018), among other variables, are important at the moment of explaining local and regional diversity gradients (MontañoCentellas et al. 2019). This is the first of a series of papers assessing the distribution of small, non-flying mammals along the steep elevational range of the Bolivian Yungas and much more detailed analysis, with data of greater altitudinal and longitudinal amplitude, will be forthcoming.

The Andes present two cordilleras running on an approximate N-S direction in Bolivia, each with similar geological histories, but exposed to very dissimilar ecological and environmental forces and a different pool of potential species of mammals. We urge the continuous effort of documenting general patterns of species diversity along each of these branches of the Andes, as well as studies that focus on trophic relationships, and that document morphological and categorical features of the resident species. Only then, will we be able to disentangle functional, phylogenetic and taxonomic dimensions of biodiversity and assess how each is apportioned across space and time.

\section{Acknowledgements}

We dedicate this work to the memory of Dr. Sydney Anderson, a gentleman and a scientist. His work in Bolivia laid the foundations for the launching of the golden age of Bolivian mammalogy. This project was been funded by GA CR Funding 14-36098G and MSMT Funding LO1415. Global Change Research Institute. We want to thank Bolivian Collection of Fauna - Institute of Ecology - Biology Career of the UMSA, for their logistical and environmental support for the work of the office and identification of the specimens; and to all the people who collaborated in the development of the fieldwork, and to Lic M. Ocampo for his help in the elaboration of the geographical location map.

\section{Literature cited}

Ad Hoc Committee For Animal Care Guidelines. 1998. Guidelines for the capture, handling, and care of mammals as approved by the American Society of Mammalogists. Journal of Mammalogy 79:1416-1431.

Aguirre, L. F., T. Tarifa, R. B. Wallace, N. Bernal, L. Siles, E. Aliaga-Rossel, and J. Salazar-Bravo. 2019. Lista actualizada y comentada de los mamíferos de Bolivia. Ecología en Bolivia 54:107-147.

Anderson, S. 1997. Mammals of Bolivia, taxonomy y distribution. Bulletin of the American Museum of Natural History 231:1-652.

Andrade, A., And A. Monjeau. 2014. Patterns in community assemblage and species richness of small mammals across an altitudinal gradient in semi-arid Patagonia, Argentina. Journal of Arid Environments 106:18-26.

Bateman, B. L., A. S Kutt, E. P. Vanderduys, and J. E. Kemp. 2010. Small-mammal species richness and abundance along a tropical altitudinal gradient: an Australian example. Journal of Tropical Ecology 26:139-149.

BeCK, S. 1988. Las ecorregiones ecológicas y las unidades fitogeográficas de Bolivia. Pp. 233-267 in Manual de Ecología (de Morales, C. ed.). Instituto de Ecología-UMSA. La Paz, Bolivia.

Begon, M., R. C. Townsend, ANd J. L. Harper. 2006. Ecology: from individuals to ecosystems 4th ed. Ed Blackwell Publishing. Oxford, U.K.

Brown, J. H. 1988. Species diversity. Pp 57-89 in Analytical biogeography (Myers A., and R. S. Giller, eds.). Chapman and Hall. Chicago, Illinois, U.S.A.

Brown, J. H. 2001. Mammals on mountainsides: elevational patterns of diversity. Global Ecology and Biogeography 10:101-109.

Brown, J. H., AND A. Kodric-Brown. 1977. Turnover rates in insular biogeography: effect of immigration on extinction. Ecology 58: 445-449.

Brown, J. H., S. K. M. Ernest, J. M. Parody, and J. P. Haskell. 2001. Regulation of diversity: maintenance of species richness in changing environments. Oecologia 126:321-332

Chaneton, E. J., and J. M. Facello. 1991. Disturbance effects on plant community diversity: spatial scales and dominance hierarchies. Vegetatio 93:143-155.

Colwell, R. K., AND G. C. HuRtt. 1994. Nonbiological gradients in species richness and a spurious Rapoport effect. American Naturalist 144:570-595.

Colwell, R. K., AND D. C. Lees. 2000. The mid-domain effect: geometric constraints on the geography of species richness. Trends in Ecology and Evolution 15:70-76.

Currie, D. J., AND J. T. KerR. 2008. Tests of the mid-domain hypothesis: a review of the evidence. Ecological Monographs 78:3-18.

Cruz, L. E., C. Lorenzo, O. G. Retana, and E. C. Sántiz. 2010. Interspecific variability in the abundance of small rodents in the highlands of Chiapas, Mexico. Therya 1:129-136.

de Oliveira, J. A., ANd P. R. Gonçalves. 2015. Genus Oxymycterus 
Water house, 1837. Pp. 247-268 in Mammals of South America, Volume 2. Rodents (Patton J. L., U. F. J. Pardiñas and G. D'Elía, eds.). The University of Chicago Press. Chicago, U.S.A.

Dreiss, L. M., K. R. Burgio, L. M. Cisneros, B. T. Klingbeil, B. D. Patterson, S. J. Presley, and M. R. Willig. 2015. Taxonomic, functional, and phylogenetic dimensions of rodent biodiversity along an extensive tropical elevational gradient. Ecography 38:876-888.

Escalante, E. T. 2003. ¿Cuántas especies hay? Los estimadores no paramétricos de Chao. Benemérita Universidad Autónoma de Puebla Elementos: Ciencia y Cultura 52:53-56.

Gannon, W. L., R. S. Sikes, and The Animal Care And Use Committee Of The American Society of Mammalogists. 2007. Guidelines of the American Society of Mammalogists for the use of wild mammals in research. Journal of Mammalogy 88: 809-823.

Hammer, Ø., D. A. T. Harper, and P. D. Ryan. 2001. PAST: Paleontological statistics software package for education and data analysis. Palaeontologia Electronica 4:1-9.

Heaney, L. R. 2001. Small mammal diversity along elevational gradients in the Philippines: an assessment of patterns and hypotheses. Global Ecology and Biogeography 10:15-39.

Herzog, S. K., M. Kessler, and K. Bach. 2005. The elevational gradient in Andean bird species richness at the local scale: a foothill peak and a high-elevation plateau. Ecography 28:209-222.

Hill, J. K., and K. C. Hamer. 2004. Determining impacts of habitat modification on diversity of tropical forest fauna: the importance of spatial scale. Journal of Applied Ecology 41:744-754.

Hurtado, N., and V. Pacheco. 2017. Revision of Neacomys spinosus (Thomas, 1882) (Rodentia: Cricetidae) with emphasis on Peruvian populations and the description of a new species. Zootaxa 4242:401-440.

IDENTIDAd MAdidi, AND SERNAP. 2019. Informe de la expedición científica Identidad Madidi 2016. Relevamientos de biodiversidad en el Parque Nacional y Área de Manejo Integrado Madidi. La Paz, Bolivia.

KELT, D. 1999. Assemblage structure and quantitative habitat relations of small mammals along an ecological gradient in the Colorado Desert of southern California. Ecography 22:659-673.

KöRneR, C. 2007. The use of 'altitude' in ecological research. Trends in Ecology and Evolution 22:569-574.

Lomolino, M. V. 2001. Elevation gradients of species-density: historical and prospective views. Global Ecology and Biogeography 10:3-13.

Luévano, J., E. Mellink, M. E. Riojas-López, and J. L. Flores-Flores. 2008. Comunidad de roedores nocturnos en un ecotono de matorrales micrófilos y zacatal gipsófilo en San Luis Potosí, México. Revista Mexicana de Biodiversidad 79:197-203.

MacArthur, R. H., and J. W. MacArthur. 1961. On bird species diversity. Ecology 42:594-598.

McCaIN, C. M. 2003. North American desert rodents: a test of the mid-domain effect in species richness. Journal of Mammalogy 84:967-980.

McCain, C. M. 2004. The mid-domain effect applied to elevational gradients: species richness of small mammals in Costa Rica. Journal of Biogeography 31:19-31.

McCaIn, C. M. 2005. Elevational gradients in diversity of small mammals. Ecology 86:366-372.

McCAIN, C. M. 2007. Area and mammalian elevational diversity. Ecology 88:76-86.

McCaln, C. M. 2009. Vertebrate range sizes indicate that mountains may be "higher" in the tropics. Ecology Letters 12:550-560.

Mo Nor, S. M. D. 2001. Elevational diversity patterns of small mammals on Mount Kinabalu, Sabah, Malaysia. Global Ecology and Biogeography 10:41-62.

Mena, J. L., S. Solari, J. P. Carrera, L. F. Aguirre, and H. Gómez. 2011. Small mammal diversity in the Tropical Andes: an overview. Pp. 260-27 in Climat Change and Biodiversity in the Tropical Andes (Herzog, S. K., R. Martínez, R. M. Jørgensen, and H. Tiessen, eds.). São José dos Campos, InterAmerican Institute for Global Change Research and Scientific Committee on Problems of the Environment. Sao Paulo, Brazil.

Montaño-Centellas, F. A., C. McCain, and B. A. Loiselle. 2020. Using functional and phylogenetic diversity to infer avian community assembly along elevational gradients. Global Ecology and Biogeography, 29:232-245.

Moya, I., E. Aliaga-Rosel, A. Rico, J. Salazar-Bravo, and R. Galeón. 2015. Los mamíferos del valle de La Paz. Pp. 671722 in Historia Natural de un Valle en los Andes: La Paz (Moya M. I., R. I. Meneses, and J. Sarmiento, eds.). Museo Nacional de Historia Natural. La Paz, Bolivia.

Navarro, G., and M. Maldonado. 2002. Geografía ecológica de Bolivia: Vegetación y ambientes acuáticos. Centro de Ecología Simón I. Patiño. Santa Cruz-Bolivia.

Navas, C. A. 2006. Patterns of distribution of anurans in high Andean tropical elevations: insights from integrating biogeography and evolutionary physiology. Integrative and comparative Biology 46:82-91.

NoRušIs, M J. AND SPSS INC. SPSS. 1990. Advanced Statistics Users Guide. SPSS Inc. Chicago, U.S.A.

Novillo, A., AND R. A. OJedA. 2014. Elevation patterns in rodent diversity in the dry Andes: disentangling the role of environmental factors. Journal of Mammalogy 95:99-107.

Pacheco, V. 2015. Genus Thomasomys Coues, 1884. Pp. 617682 in Mammals of South America, Volume 2. Rodents (Patton J. L., U. F. J. Pardiñas, and G. D'Elía, eds.). The University of Chicago Press. Chicago, U.S.A.

Pardiñas, U. F. J., P. Teta, P. E. Ortiz, J. P. Jayat, and J. SalazarBravo. 2015a. Genus Necromys Ameghino, 1889. Pp. 232247 in Mammals of South America, Volume 2. Rodents (Patton J. L., U. F. J. Pardiñas and G. D'Elía, eds.). The University of Chicago Press. Chicago, U.S.A.

Pardiñas, U. F. J., P. Teta, D. Alvarado-Serrano, L. Geise, J. P. Jayat, P. E. Ortiz, P. R. Gonçalves, AND G. D'Elía. 2015b. Genus Akodon Meyen, 1833. Pp. 144-204 in Mammals of South America, Volume 2. Rodents (Patton J. L., U. F. J. Pardiñas, and G. D'Elía, eds.). The University of Chicago Press. Chicago, U.S.A.

Patterson, B. D., P. L. Meserve, and B. K. Lang. 1989. Distribution and abundance of small mammals along an elevational transect in temperate rainforests of Chile. Journal of Mammalogy 70:67-78.

Patterson, B. D., D. F. Stotz, S. Solari, J. W. Fitzpatrick, and V. PaCheco. 1998. Contrasting patterns of elevational zonation for birds and mammals in the Andes of southeastern Peru. 
Journal of Biogeography 25:593-607.

Patton, J. L. 1986. Patrones de distribución y especiación de la fauna de mamíferos de los bosques nublados andinos del Perú. Anales del Museo de Historia Natural de Valparaíso 17:87-94.

Patton, J. L., AND M. F. Smith. 1992. mtDNA Phylogeny of Andean mice: a test of diversification across ecological gradients. Evolution 46:174-183.

Patton J. L., And R. N. Leite. 2015. Genus Proechimys J. A. Allen, 1899. Pp. 950-989 in Mammals of South America, Volume 2. Rodents (Patton J. L., U. F. J. Pardiñas, and G. D'Elía, eds.). The University of Chicago Press. Chicago, U.S.A.

Patton, J. L., M. Z. Da Silva, And R. J. Malcolm. 2000. Mammals of the Rio Juruá and the evolutionary and ecological diversification of Amazonia. Bulletin of the American Museum of Natural History 244:306.

Patton, J. L., U. F. J. Pardiñas, ANd G. D'Elía (Ed). 2015. Mammals of South America, Volume 2. Rodents. The University of Chicago Press. Chicago, U.S.A.

Percequillo A. R. 2015. Genus Nephelomys Weksler, Percequillo, y Voss, 2006. Pp. 377-390 in Mammals of South America, Volume 2. Rodents (Patton J. L., U. F. J. Pardiñas, and G. D'Elía, eds.). The University of Chicago Press. Chicago, U.S.A.

Pielou, E. C. 1966. Species diversity and pattern diversity in the study of ecological succession. Journal of Theoretical Biology 10:370-383.

Presley, S. J., L. M. Cisneros, B. D. Patterson, and M. R. Willig. 2012. Vertebrate metacommunity structure along an extensive elevational gradient in the tropics: a comparison of bats, rodents and birds. Ecological Biogeography 21:968-976.

Quintero, I., AND W. Jetz. 2018. Global elevational diversity and diversification of birds. Nature 555: 246-250.

Raнвек, C. 1995. The elevational gradient of species richness: a uniform pattern? Ecography 18:200-205.

ReIG, O. A. 1986. Diversity patterns and differentiation of high Andean rodents. Pp. 404-439 in High altitude tropical biogeography (Monasterio M., and F. Vuilleumier, eds.). New York: Oxford University Press. New York, U.S.A.

Ribera-Arismendi, M. O. 1995. Caminos de Cotapata. Instituto de Ecología, La Paz-Bolivia.

RıcKart, E. A. 2001. Elevational diversity gradients, biogeography and the structure of montane mammal communities in the intermountain region of North America. Global Ecology and Biogeography 10:77-100.

RosenzWeIG, M. L. 1992. Species diversity gradients: we know more and less than we thought. Journal of Mammalogy 73:715-730.

Salazar-Bravo, J. 2015. Genus Auliscomys Osgood, 1915. Pp. 472-479 in Mammals of South America, Volume 2. Rodents (Patton J. L., U. F. J. Pardiñas, and G. D'Elía, eds.). The University of Chicago Press. Chicago, U.S.A.

Salazar-Bravo, J., and T. L. Yates. 2007. A new species of Thomasomys (Cricetidae: Sigmodontinae) from central Bolivia. Pp. 747-774 in The Quintessential Naturalist: Honoring the Life and Legacy of Oliver P. Pearson (Kelt, D. A., E. P Lessa, J. Salazar-Bravo, and J. L Patton, eds.). University of California Publications in Zoology 134: 1-981.

Salazar-Bravo, J., T. L. Yates, and M. Zalles. 2002. Los Mamíferos de Bolivia. Pp. 65-113 in Diversidad y Conservación de los Mamíferos de Latino América (Ceballos G., and J. Simmoneti, eds.). CONABIO-UNAM, México.

Salazar- Bravo, J., E. Yensen, T. Tarifa, and T. L. Yates. 2002. Distributional records of Bolivian mammals. Mastozoología Neotropical 9:70-78.

Salazar-Bravo, J., T. Tarifa, L. F. Aguirre, E. Yensen, and T. L. Yates. 2003. Revised Checklist of Bolivian Mammals. Occasional Papers, Museum of Texas Tech University 220:1-27.

SÁnchez-Cordero, V. 2001. Elevation gradients of diversity for rodents and bats in Oaxaca, Mexico. Global Ecology and Biogeography 10:63-76.

Sanders, N.J., And C. RahbeK. 2012. The patterns and causes of elevational diversity gradients. Ecography 35:1-3.

Santos, A., M. A. Briones, And R. López. 2007. Diferencias en algunos parámetros demográficos de Oryzomys chapmani (Rodentia: Muridae) asociadas a tres estados sucesionales de bosque mesófilo de montañas en Oaxaca, México. Acta Zoológica Mexicana 23:123-137.

Sevilla-Callejo, M., and R. Mata-Olmo. 2007. Introducción a las dinámicas territoriales en el área oriental del Parque Nacional y ANMI Cotapata (La Paz, Bolivia). Ecología en Bolivia 2:1-14.

Soları, S. 2007. Trophic Relationships Within a Highland Rodent Assemblage from Manu National Park, Cusco, Peru. Pp. 225-240, in The Quintessential Naturalist: Honoring the Life and Legacy of Oliver P. Pearson (Kelt, D. A., E. P. Lessa, J. Salazar-Bravo, and J. L. Patton, eds.). University of California Publications in Zoology 134:1-981.

Solari, S., V. Pacheco, L. Luna, P. M. Velazco, and B. D. Patterson. 2006. Mammals of the Manu Biosphere Reserve. Fieldiana: Zoology, n.s. 110:13-22.

Stevens, G. C. 1992. The elevational gradient in altitudinal Range: An extension of Rapoport's latitudinal rule to altitude. American Naturalist 140:893-911.

Swenson, J. J., B. E. Young, S. Beck, P. Comer, J. H. Córdova, J. Dyson, D. Embert, F. Encarnación, W. Ferreira, I. Franke, D. Grossman, P. Hernandez, S. K. Herzog, C. Josse, G. Navarro, V. Pacheco, B. A. Stein, M. Timaná, A. Tovar, C. Tovar, J. Vargas, and C. M. Zambrana-Torrelio. 2012. Plant and animal endemism in the eastern Andean slope: challenges to conservation. BMC. Ecology 12:1-18.

Terborgh, J. 1977. Bird species diversity on an Andean elevational gradient. Ecology 8:1007-1019.

Tribe, C. J. 2015. Genus Rhipidomys Tschudi, 1845. Pp. 583617 , in Mammals of South America, Volume 2. Rodents (Patton J. L., U. F. J. Pardiñas and G. D'Elía, eds.). The University of Chicago Press. Chicago, U.S.A.

Vargas, J., P. Flores, and J. Martínez. 2018. Pequeños mamíferos en dos áreas protegidas de la vertiente oriental boliviana, considerando la variación altitudinal y la formación vegetacional. Revista Virtual Redesma. http://revistavirtual. redesma.org/vol2/pdf/ambiental/mamiferos.pdf.

Villalpando, G. 2004. Variación altitudinal y temporal de roedores y marsupiales en el área del cerro Hornuni del Parque Nacional y Área de manejo Integrado Cotapata. Tesis de Grado, Carrera de Biología- Universidad Mayor de San Andrés. La Paz, Bolivia 104p.

Villalpando, G., J. Vargas and J. Salazar-Bravo. 2006. First record of Rhagomys (Mammalia: Sigmodontinae) in Bolivia. Mastozoología Neotropical 13:143-149.

Vivar, E. 2006. Análisis de distribución altitudinal de 
mamíferos pequeños en el Parque Nacional YanachagaChemillén, Pasco, Perú. Tesis de Maestría. Lima: Facultad de Ciencias Biológicas, Universidad Nacional Mayor de San Marcos. Lima, Perú.

Voss, R. S., T. Tarifa and E. Yensen. 2004. An introduction to Marmosops (Marsupialia: Didelphidae), with the description of a new species from Bolivia and notes on the taxonomy and distribution of other Bolivian forms. American Museum Novitates 3466:1-40.

Wallace, R. B., H. Gómez, Z. R. Porcel, and D. I. Rumiz (Eds.). 2010. Distribución, Ecología y Conservación de los Mamíferos Medianos y Grandes de Bolivia. Centro de Ecología Difusión Simón I. Patiño. Santa Cruz,Bolivia.

Weksler, M., A. R. Percequillo, and R. S. Voss. 2006. Ten new genera of Oryzomyine rodents (Cricetidae: Sigmodontinae). American Museum Novitates 3537:1-29.

WhittakeR, R. H. 1977. Evolution of species diversity in land communities. Evolutionary Biology 10:1-67.

Wiluig, M. R., and S. J. Presley. 2016. Biodiversity and metacommunity structure of animals along altitudinal gradients in tropical montane forests. Journal of Tropical Ecology 32:421-436.

Willig, M. R., and E. A. Sandlin. 1992. Gradients of species density and species turnover in New World bats: a comparison of quadrat and band methodologies. Pp. 81-96 in Latin American Mammalogy (Mares M. A., and D. J. Schmidly, eds.). University of Oklahoma Press, Norman. Oklahoma, U.S.A.

$Z_{A R,}$ J. H. 2010. Biostatistical Analysis, 5th ed. Northern Illinois University. Upper Saddle River, New Jersey: Prentice Hall. New Jersey, U.S.A.

\section{Associated editor: Sergio Solari}

Submitted: April 22, 2020; Reviewed: July 2, 2020;

Accepted: August 24, 2020; Published on line: September 25, 2020. 